\title{
Monitoring the post-irradiation E. coli survival patterns in environmental water matrices: implications in handling solar disinfected wastewater
}

\author{
Stefanos Giannakis ${ }^{1,2,3}$, Ana Isabel Merino Gamo ${ }^{3}$, Efthymios Darakas ${ }^{1}$, Antoni Escalas- \\ Cañellas $^{2,4}$, César Pulgarin ${ }^{3, *}$ \\ ${ }^{1}$ Laboratory of Environmental Engineering and Planning, Department of Civil Engineering, Aristotle University of \\ Thessaloniki, 54624 Thessaloniki, Greece \\ ${ }^{2}$ Laboratory of Control of Environmental Contamination, Institute of Textile Research and Industrial Cooperation of \\ Terrassa (INTEXTER), Universitat Politècnica de Catalunya, Colom 15, 08222 Terrassa, Catalonia, Spain \\ ${ }^{3}$ Swiss Federal Institute of Technology, Lausanne, Institute of Chemical Sciences and Engineering, 1015 Lausanne, \\ Switzerland
}

${ }^{4}$ Department of Chemical Engineering \& Terrassa School of Engineering, Universitat Politècnica de Catalunya, Colom 1, 08222, Terrassa, Catalonia, Spain

*Corresponding author: César Pulgarin, Tel: +41216934720; Fax: +41216936161;

E-mail: cesar.pulgarin@epfl.ch

\begin{abstract}
In this study, simulated solar disinfection of secondary effluent was followed by dark storage at different temperatures or different receiving water matrices. E. coli illumination was followed by 3-day monitoring of the bacterial population and its adaptation in different temperature conditions in the dark. The subsequent survival was linked to the dose received during exposure to light, and results were obtained on the environmentally induced prolongation of survival, maintenance of population or excessive growth, at 4,20 and $37^{\circ} \mathrm{C}$, respectively. An additional set of experiments at $20^{\circ} \mathrm{C}$ was subjected to dilution in $E$. coli-free synthetic wastewater, water from Lake Leman, (synthetic) seawater and Mili-Q water. Post-irradiation
\end{abstract}


monitoring was also conducted, studying $50 \%, 10 \%$ and $1 \%$ dilution rates, and the results were attributed to the two parameters of dilution medium and dilution ratio. However, different responses were found based on the acquired dose during pre-treatment. This indicates the importance of the illumination prior to storage, and the preference of bacteria in some matrices over the others. Survival was linked to initial population, dose, dilution and medium; shorter illumination times are to be considered according to the receiving water matrix.

Keywords: Solar disinfection, E. coli survival, environmental influence, regrowth, dilution, aqueous matrices 


\section{Introduction}

Modern wastewater treatment plants use either automated control systems [1], or specially trained personnel to handle the operation and management of their facilities. For this reason, many works have shown concern for their high operating and maintenance costs [2]. Other studies, to provide an effective alternative, suggest the simplicity of natural systems [3, 4]. These systems are simpler and cost-effective, while ensuring no compromise is made in terms of efficiency. As a result, a variety of solutions is offered to the developed countries. However, one must consider the available solutions in the cases that neither of the key factors in applying modernized wastewater treatment systems can be acquired. Rural or isolated communities or even developing countries are unable to support technologically advanced solutions. Therefore, research interest should be directed to more natural-based approaches, such as waste stabilization ponds $[5,6]$ or constructed wetlands [7].

However, the presence of the developing countries around earth's Equator, leads to the reception of a vast number of sunny days per year [8]. The combination of this supply with the un-feasibility of technologically demanding solutions, makes solar treatment systems a sustainable solution, which could improve the poor sanitation conditions often encountered. For more than 30 years [9, 10 and many more] priority has been given to water disinfection, since people suffered from waterborne diseases $[11,12]$. These applications were focused in applying solar disinfection techniques for the production of safe drinking water, with remarkable results wherever it was applied $[13,14]$. Nevertheless, it can be assumed that waterborne diseases, which were connected to microorganisms of gastro-intestinal track, were result of fecal pollution due to poor sanitation conditions. Therefore, the improvement of these conditions will improve the quality of water supplies. Literature suggests the recommended features that the candidate water must fulfill [15], the required dose for a variety of microorganisms [16] and studies about the evolution of water disinfection experiments after the end of treatment [17]. 
The application of solar treatment systems requires two main axis of caution: disinfection and post-irradiation events. Over the years, solid knowledge concerning the exploitation of solar power to reduce microorganisms in water has been accumulated, which we could extrapolate to wastewater $[13,18$, and 19]. These results include works water disinfection in various treatment methods and media, such as PET bottles [20], or CPC reactors [21]. For wastewater, the most feasible processes in the context of developing countries could be superficial flow constructed wetlands [22] or waste stabilization ponds [23].

The second axis deals with the fate of microorganisms, once disinfection is over. There are a number of works concerning the occurrence of microorganisms in natural waters, such as rivers [24], lakes [25], estuarine [26, 27] or brackish water [28] and seawater [29, 30]. However, only few studies deal with the microbial post-irradiation fate of microorganisms when treated wastewaters are discharged in these water matrices (for instance [31, 32]). What is mostly discussed is the fate of microorganisms occurring in different water types, while others include the simultaneous application of solar irradiation; Yukselen et al [33] have studied the inactivation of bacteria in seawater, Jenkins et al [34] the die-off in pond waters etc., thus providing information on the concurrent action of adaptation and illumination.

Considering the parameters that affect microorganism survival and regrowth in natural context, reactivation of bacteria is possible when the treated effluent is released in natural water bodies, although it depends on many factors. Chan and Killick [31] performed a series of experiments that proved the correlation between temperature and regrowth potential. These findings were verified and extended by Shang et al [35], who stated the elasticity of the regrowth dynamics response between 10 and $35^{\circ} \mathrm{C}$, observing the minimization of the potential under $10^{\circ} \mathrm{C}$. The experiments of Munshi et al [36] proved that bacteria recover within 24h when the proper conditions are given. Within the same framework, it was shown [35] that the supply of nutrients in the matrix demonstrated higher final numbers. Rincon and Pulgarin [17] observed that after solar illumination and reproduction of the same experiments in the laboratory, almost all samples that were conducted with natural water, which contained even lower concentrations of 
dissolved organic carbon, presented regrowth in dark conditions. This was unexpected, since low organic matter concentration should have limited the regrowth, as Tassoula [37] showed, because low COD values lower survival dynamics. Finally, natural water bodies as a receiving medium are interesting, because it is believed that enteric bacteria may survive in natural waters but are not able to multiply themselves [38]. In natural aquatic environments carbon availability and temperature are much lower and, therefore, the expected specific growth rates of enteric bacteria are lower [39].

In this study, we investigate the bacterial pathway from the moment they are introduced into the disinfection system, the effect of solar dose and the introduction into several water matrices. While keeping the solar dose at same levels, treated secondary effluent is first kept in a range of temperature $\left(4,20\right.$ and $\left.37^{\circ} \mathrm{C}\right)$, so as to test regrowth dynamics as a function of temperature. In another context, previously illuminated samples are lead into i) untreated wastewater (E. colifree synthetic secondary effluent), ii) lake water, iii) sea water and iv) distilled water, in order to assess the effect of the receiving water body on the regrowth potential, the survival and the mortality rate. The same assessment was carried out in a series of dilutions $(50 \%, 10 \%$ and $1 \%$ ), with the aim to systematically investigate the effects of different osmotic conditions and nutrient content. We aim to locate the ability of bacteria to adapt in the environment while being pre-stressed by solar light and the variation of the environmental conditions on the required dose for safe handling of the treated samples. The examination of their post-irradiation period will provide information on the constraints that limit discharge to the natural environment and consequently, on the risk of downstream contamination in a similar application.

\section{Materials and Methods}

\subsection{Water matrices}




\subsubsection{Synthetic wastewater preparation}

Analytical preparation of the synthetic secondary effluent and the specifications concerning the microorganism strain used in this research, are described in detail elsewhere [40]. In summary, the synthetic wastewater composition was $160 \mathrm{mg} / \mathrm{L}$ peptone, $110 \mathrm{mg} / \mathrm{L}$ meat extract, $30 \mathrm{mg} / \mathrm{L}$ urea, $28 \mathrm{mg} / \mathrm{L} \mathrm{K} \mathrm{HPO}_{4}, 7 \mathrm{mg} / \mathrm{L} \mathrm{NaCl}, 4 \mathrm{mg} / \mathrm{L} \mathrm{CaCl} 2 \cdot 2 \mathrm{H}_{2} \mathrm{O}$ and $2 \mathrm{mg} / \mathrm{L} \mathrm{Mg} \mathrm{SO}_{4} \cdot 7 \mathrm{H}_{2} \mathrm{O}$, with 250 $\mathrm{mg} / \mathrm{L}$ COD. The chemicals were used as received. A $10 \%$ dilution of the said wastewater was inoculated with $E$. coli, to form a suspension containing $10^{6} \mathrm{CFU} / \mathrm{mL}$ and bear organic carbon values closer to the desired ones [61].

2.1.2. Lake Leman water, synthetic seawater and wastewater, and Mili-Q water specifications

The physicochemical characteristics of Lake Leman water and the composition of synthetic seawater are presented in Table 1 [41]. Mili-Q water is characterized by $18.2 \mathrm{M} \Omega \cdot \mathrm{cm}$ resistivity at $25{ }^{\circ} \mathrm{C}$. Lake water was heat-sterilized to avoid the effects of indigenous microorganisms and focus only on the physicochemical characteristics of the employed water matrices, while artificial seawater and Mili-Q water were also heat-sterilized prior to use, to avoid contamination.

\subsection{Simulated solar treatment batch tests}

Bacterial inactivation took place in $50 \mathrm{~mL}$ batch tests, in glass reactors of $65 \mathrm{~mL}$ total capacity that allow UVB transmission, while being mildly stirred with a magnetic stirrer (approx. 150 rotations per minute). Irradiation was simulated and provided by a CPS Suntest apparatus, bearing a $150 \mathrm{~W}$, air-cooled xenon lamp. This lamp emits $\sim 0.5 \%$ of the total photons in the UVB area, $\sim 7 \%$ in the UVA and the rest, above $400 \mathrm{~nm}$ follow the solar spectrum. Also, a cut-off filter set at $290 \mathrm{~nm}$ ensured no UVC is received and a glass filter blocks IR transmission to the 
sample. The global and UV intensities were measured by a Kipp \& Zonen CM3 and CUV3 radiometer.

\subsection{Sampling, bacterial enumeration and post-irradiation monitoring}

Sampling was done from the body of the sample under stirring, by sterile syringes. Aliquots were made when needed, so as to achieve bacterial counts around $15-150 \mathrm{CFU} / \mathrm{mL}$. Enumeration took place in non-selective medium (PCA) by the pour-plating method, at least in duplicates and from two consecutive aliquots. The detection limit was reported as $10 \mathrm{CFU} / \mathrm{mL}$ for diluted and $1 \mathrm{CFU} / \mathrm{mL}$ for undiluted samples, respectively [62]. Incubation for $24 \mathrm{~h}$ at $37^{\circ} \mathrm{C}$ provided the bacterial population.

Every 30 min, a sample was taken and was kept in the dark for the total duration of the monitoring period. Temperature control experiments were stored for $72 \mathrm{~h}$ ( 3 days), while dilution experiments were kept for $120 \mathrm{~h}(5$ days $)$ at room temperature $\left(20^{\circ} \mathrm{C}\right)$. Daily monitoring of the bacterial population was made by sampling from the stored samples exactly $24 \mathrm{~h}$ after the initial acquisition time of each sample. Samples were kept in sterile plastic vials in the dark during the monitoring period. A graphical representation is given in Figure 1.

Temperature dependence experiments were done at 4,20 and $37^{\circ} \mathrm{C}$ (refrigeration, ambient temperature and incubator temperatures). Dilutions $(50 \%, 10 \%$ and $1 \%)$ were made in sterile synthetic wastewater, Lake Leman water, synthetic seawater and Mili-Q water. The last groups of tests in Mili-Q water represent a control experiment, rather unlikely to achieve in real environmental context, but will offer great insight on the way osmotic pressure and presence/absence of food acts on pre-stressed bacteria. 


\section{Experimental results}

3.1. Temperature experiments: post-irradiation modification of storage temperature and its effects on bacterial repair

The first set of experiments studies the modification of storage temperature conditions for the solar-treated samples. The samples were exposed in simulated solar light, with the intensity set at $1000 \mathrm{~W} / \mathrm{m}^{2}$, an achievable solar intensity in real context. In Figure 2 it is observed that the disinfection kinetics reveal a shoulder-lag phase, followed by log-linear decay until the end of a 4-hour period that was required to fully inactivate microorganisms. In reality, almost $90 \%$ of bacteria were inactivated in $3 \mathrm{~h}$ and the excess 1 - $\mathrm{h}$ dose ensured zero counts at the end of the experiment. Post-treatment storage of the samples drawn every $30 \mathrm{~min}$ took place in three different conditions, 4,20 and $37^{\circ} \mathrm{C}$, in order to recreate the conditions usually encountered by microorganisms.

In this approach, there are some constraints to be considered, such as the nature of the target microorganism: Escherichia coli is a typical mesophilic microorganism, that usually thrives around $35-39^{\circ} \mathrm{C}$, presenting a maximum growth rate around these temperatures. Lowering temperature will result in deceleration of their metabolic rhythm [42], while the expected behavior at $4^{\circ} \mathrm{C}$ would be a stabilization in the minimum metabolic activity required to sustain life. Also, the chemical composition of the matrix is of high importance, considering the abundance of nutrients and salts present within it. Marugan et al [43] have underlined the importance on $\mathrm{Mg}$ and $\mathrm{K}$ salts for the maintenance of bacterial life and Caballero et al [44] highlighted the aid nutrients provide in the growth of bacteria in water matrices. Therefore, optimal support conditions for bacterial development is expected, as seen in previous works with the same wastewater matrix $[40,61]$. 
Figure 2 presents the monitoring of the bacterial population for three days after the sampling time. First of all, the effects the exposure (UV dose) has on bacterial survival are demonstrated. Generally, increasing the dose decreases bacterial survival. It can be also seen that until the corresponding dose of 90-min exposure to sunlight, bacteria still maintain their ability to recover their damage and, after a lag phase, once again increase their population. Conversely, from 120 min of treatment and more, damage is permanent; bacterial population is lowering, as days pass, indicating cells that are unable to recover their damage and probably, cellular senescence is taking place [45]. It is known that the accumulation of photo-products inside the cell [46], makes bacteria unable to sustain normal life functions, through the damages in the respiratory chain [47], in DNA [46] etc.

Considering the above, it is interesting to observe the differences low (unfavorable) and high (favorable) temperatures inflict on bacterial survival. In Figure 2a, the deceleration of bacterial metabolism is visible. Since the samples have been subjected to the same irradiation energy, under the same experimental conditions, it is normally expected to have the same evolution, when it comes to their survival. However, i) suspended growth rates in lightly or non-irradiated samples and ii) prolongation of the bacterial survival is observed, compared to the situation at $20^{\circ} \mathrm{C}$. For instance, the kinetic curves that correspond to 150,180 and 210 min of pre-treatment, reveal a significant delay towards their respective $20^{\circ} \mathrm{C}$ ones. This is attributed to the formation of more resistant forms of cell structure as a defense against low temperature, which includes low metabolism rates and nutrient uptake. As it seems, either reparation of photo-induced damage or, along with delayed metabolic action, a delayed programmed cell death [48] triggered by light exposure is observed.

In contrast, cells that remained at $37^{\circ} \mathrm{C}$, present altered kinetic curves compared to their respective ones in lower temperatures. Firstly, in Figure 2c, significant changes are visible in low-dose treatment times, where growth is orders of magnitude higher than the respective one at $4^{\circ} \mathrm{C}$. But even in high irradiation doses, samples that were treated for $180 \mathrm{~min}$ presented different behavior: at $4^{\circ} \mathrm{C}$ slightly decreased their numbers, decayed shortly after treatment 
stopped when metabolism was increased $\left(20^{\circ} \mathrm{C}\right)$, even present a mild growth at $37^{\circ} \mathrm{C}$. At this temperature, the conditions for growth are favorable, and bacterial survival is promoted. Another possibility, since no total disinfection was achieved, the alive fraction of bacteria compensated for the fatally injured ones, in terms of numbers. In the existence of a declining number due to damage and a growing one, due to comfortable conditions, the numerical balance is in favor of growth. Finally, in all experiments, whenever total inactivation was reached during the illumination period, no regrowth was observed in any samples, thus indicating the permanent nature of the inactivation due to light exposure.

\subsection{Dilution experiments: post-irradiation modification of the receiving aqueous matrix and long-term monitoring of bacterial survival}

The following experiments study the introduction of variously pre-irradiated wastewater in different water matrices, potential environmental receiving media of photo-treated wastewater. While keeping temperature constant at $20^{\circ} \mathrm{C}$, wastewater is diluted in three rates $(50 \%, 10 \%$ and $1 \%$ ) in four matrices: (E.coli-free synthetic) wastewater, lake water, (simulated) sea water and Mili-Q water (as a reference). The matrices represent some conditions found in real context, and the bacterial response was monitored for 5 days in each case.

\subsubsection{Dilution in fresh (synthetic) wastewater}

Figure $3(a-c)$ present in a summarized way the results of bacterial monitoring for a period of five days after the irradiation. The inset presents the disinfection experiment from which sample is taken every $30 \mathrm{~min}$, followed by the dark storage. Figures $3 a$ to $3 c$ represent a dilution of the original disinfected sample of 50,10 and $1 \%$ respectively, over the untreated effluent. This dilution in wastewater serves a double purpose: first of all, after the treatment there is a remaining bacterial population, which is then submitted to halving, 10-fold and 100 -fold 
reduction. In this manner, three different cases of initial population can be assessed and the kinetics response in this case. Since the medium remains the same, normally growth pattern is expected to remain similar. Also, the second aspect of the dilution concerns the replenishment of organic substances which are subject to degradation due to solar treatment of the sample, according to Dahlen et al [49].

Therefore, in Figures $3 a$ to $3 c$ the kinetic curves of bacteria in five consecutive days, after their exposure to sunlight, are presented. Their kinetics are generally described as growth, which is then subjected to certain variations. In Figure 3a the exponential growth of almost all samples is visible, with the exception of the 180-min treated sample; after 3 hours of irradiation it is impossible for bacteria to heal the injuries caused by exposure to simulated sunlight and they rather survive until their complete decay after four days. All samples (except for the untreated) seem to grow their numbers, but after an initial delay of $24 \mathrm{~h}$. This observation is clear in samples treated for a significant portion of time (60-150 min).

The effect of dilution is visible, passing from $50 \%$ to $1 \%$ figures, mainly in the lag and decay phases. We stated that the initial sample is diluted in 3 different proportions, thus resulting in three different initial numbers of active bacteria. This difference is visible in time 0 , and as it seems it affects the growth curves, presenting longer lag phases, when growth is observed, or faster decay in the case of 180 -min pre-treatment. This is explained by the statistical probability to acquire less active or heavier injured cells from the initial sample. As light is inflicted on the sample, some bacteria are able to escape irradiation through shielding or scattering [50] and therefore, when the amount of the original sampled proportion is increased, the possibility of acquiring healthier cells is also rising. This probably explains the different behavior of the 150min treated sample, which switched from growth to decay.

Finally, when the dilution rate is high (1\%), the availability of nutrients per cell is higher than the other two cases. Knowing that degradation of organics affects the availability of nutrients for bacteria, a dilution in fresh wastewater will be beneficial for their survival. Therefore, in this case, there is less competition among the cells, resulting to excessive growth and their 
population reaches the same plateau (peak) as the previous cases with higher initial population, in the same time period (2-3 days), plus the stabilization towards the end of monitoring period versus the slight decreases observed in lower dilution rates.

\subsubsection{Dilution in Lake Leman water}

The second tested matrix was water acquired from Lake Leman. The water was unfiltered, to permit the occurrence of natural suspended solids, but heat-sterilized prior to experiments to avoid the effects of competition between seeded E. coli and indigenous microorganisms or predators [51]. Figures $4 \mathrm{a}$ to $4 \mathrm{c}$ demonstrate the results of a 5-day long monitoring of bacterial survival. In this matrix, survival of unharmed bacteria is expected for a relatively long time; there are reports for the occurrence of bacteria in water for weeks [52], even months in lake sediments [25]. However, there are no records on the responses of previously photo-treated bacteria.

In Figure $4 a$, the impact that solar dose has on bacterial survival, after $50 \%$ dilution, is demonstrated. It can be seen that bacteria can retain their cultivability for doses less than 120min exposure to sunlight, while longer exposure causes decay, faster with increasing doses. There is a lag phase visible in mid-ranged doses (60-120 min of pre-treatment); however, after 4 days all doses from 0 to 120 min result in almost similar concentrations, indicating a growth "ceiling" for these conditions.

Applying $10 \%$ dilution modifies the bacterial survival, as it can be seen in Figure $4 \mathrm{~b}$. As far as the matrix conditions are concerned, there has been a change in the availability of nutrients and baro-protective salts. This change is reflected to the kinetic curves especially of 90 and 120 min solar treatment, which change from growth to decay form. Also, 150 and 180-min curves reach a minimum $48 \mathrm{~h}$ earlier than $50 \%$ dilution, while 0 to 60 -min treatment curves present no significant alteration. This can be explained by the injury state of the cells from each dose group: it seems that cells which suffered the same amount of damage, in the higher presence of nutrients respond better and present growth instead of decay. 
Finally, Figure $4 \mathrm{c}$ presents the survival curves for $1 \%$ dilution of the original sample, clearly representing the effect of initial population decrease, as well as the shortage in nutrients. First of all, the curves are significantly lower, and growth is limited at the end of the monitoring period in lower numbers than the respective ones of $50 \%$ and $10 \%$. Both untreated and relatively mildly treated samples initiate in lower numbers and result in lower or even null counts. For instance, the 60 -min curve is now decaying more rapidly, and the 90 -min one is reaching total inactivation. After all, apart from the nutrient source, we suspect that mild osmotic forces that are also accelerating bacterial death due to pressure differences inside and outside the cell. This stress adds up to the already solar-damaged cells to result in faster decay rates.

\subsubsection{Dilution in (synthetic) seawater}

Seawater, as a receiving medium for wastewater, has been a subject of interest for a very long time and some practices have tried to model the survival [51] and growth [37] of microorganisms within it. There have been significant findings, and bacterial decay has been attributed to solar light, the co-existence with predators and the osmotic difference between the cell contents and the seawater $[53,54]$. Bacteria are being lysed usually after they release their intracellular fluids. Also, there have been many works studying the most common phenomenon of solar disinfection in estuarine or sea water [33], taking account the action of the sun. It has been stated that bacteria have even developed anti-irradiation mechanisms in order to maintain their integrity and continue replication. This bacterial response is a result of bacterial gene evolution, to protect themselves from the solar ultraviolet rays [55]. Keeping all the above into consideration, the ability of bacteria to survive after they have been exposed to sun, and therefore, sterile synthetic seawater has been used is studied, in order to exclusively quantify the amount of physicochemical stress applied on the cells.

Figure 5a demonstrates the survival kinetics for five days in $50 \%$ diluted wastewater. Although it is known from literature that the change in osmotic pressure is a fatal stress, decay is observed only in cells previously irradiated for $150 \mathrm{~min}$ and above. All other samples present a lag and 
then a growth phase, which is proportional to the dose received. There is a certain extent of osmotic difference to be achieved, in order to visualize its detrimental effects. This dilution is not very hostile, since only weak cells are subject to decay. The adaptation phase is finished in three days and then a mild growth phase initiates until the end of the study period.

After $10 \%$ dilution of the samples, (Figure $5 \mathrm{~b}$ ) almost all treated samples present decay. It is clear that even non-lethal irradiation doses are able to lead to bacterial decay within the studied time. Once again, E. coli succumb to their solar-inflicted wounds once the environment is relatively hostile. Bacteria that managed to retain their cultivability are now subject to greater stress and are lead to decay (60-120 min). The untreated, healthy cells continue to multiply and grow, as well as the 30 -min treated ones; after a 3 day survival phase, they retain their ability to grow once more, since there is $10 \%$ of the original, nutrient-rich medium.

Finally, Figure $5 \mathrm{c}$ demonstrates the fatal effect unfavorable osmolarity has on the bacterial cells. Contrary to every other case, all bacterial samples present decaying kinetic curves, even the healthy ones. The curves that presented decay in the previous (10\%) case, are declining even faster, revealing the deleterious effect of high salinity. Nutrient sources are also scarce and the first totally negative survival conditions are presented in this dilution rate.

\subsubsection{Dilution in Mili-Q water}

Figure 6 a represents a $50 \%$ dilution in Mili-Q water and the subsequent survival in a 5 -day monitoring period. The results here represent a relatively steady survival state; the same curves that decayed right away (150 and $180 \mathrm{~min}$ ) in the previous water matrices, also do so in this case. Conversely, all others present a survival over the five days, with untreated and 30-min treated samples passing directly to a growth phase, and the curves from 60-120 min present an increasing lag over the accumulated dose, and then a growth phase.

Further dilution of the treated samples reveals steady survival kinetics for 0,30 and 60 -min treatment, and decay for all other curves. In Figure 6b, initial population is decreased 5-fold and 
alongside, nutrients are becoming scarce. The kinetics have definitely been modified, and the loss of the osmotic balance is affecting all survival curves. The response is similar to the other water matrices, when bacteria were subjected to combined stress by environmental change and injury due to sunlight.

Even more, in Figure $6 \mathrm{c}$ another 10 -fold decrease in wastewater content is inflicted. The most optimistic estimation is a prolonged decay phase; no growth is observed in any sample. Also, the increase of stress conditions has shortened the survival times significantly. A decrease of 24 $\mathrm{h}$ has been observed in all cases, while the untreated, 30-min and 60-min treated samples seem to be adapting better in this environment than the heavily injured cells.

\section{Discussion}

\subsection{Bacterial response to environmental changes}

In a system designed to disinfect effluent by solar light, according to the availability of sunlight and the climatic constraints, the temperatures that can be approached, do not normally exceed $40^{\circ} \mathrm{C}$ in tropical regions [56] and normally, $4^{\circ} \mathrm{C}$ as representative in near-freezing values. Having analyzed the temperature influence as an environmental factor, the prolongation of bacterial survival due to reduced metabolic activities is noticed, and therefore, longer lifespan. Moreover, the risks of overgrown bacterial numbers due to optimal growth conditions are visible. Also, having stressed the bacteria in different light doses prior to the exposure in a variety of temperatures, one can estimate the essential exposure times to achieve a state of permanent bacterial damage, instead of the classic approach of total disinfection times. It appears that taking into consideration the dose along with temperature could lead to more accurate design estimations of the minimum treatment conditions. In that sense, apart from the studies on 
retention time for disinfection, studies on the temperature variations must be conducted in order to avoid miscalculation of the final bacterial numbers.

An interesting result of this research, considers the various stresses applied to the bacteria in "chronological" order. There have been reports of altered bacterial responses in various stresses, such as Mezrioui et al [28], which observed different survival modes when bacteria left stabilization ponds. High survival activity in ponds was followed by low resistance in brackish water and vice versa. In the majority of the experiments and almost in all dilution rates, the samples that were treated for 30 min result in the highest bacterial numbers in long term, even higher than the untreated samples. This phenomenon is attributed in two different factors. First of all, an explanation has been given by Rincon and Pulgarin [16], who attributed such effects to photo-activated bacteria. Also, it is given to understand that bacteria which have the initial illumination period, are more resistant to the other stresses that follow irradiation, namely dilution and starvation. Troussellier et al [57] have explained this paradoxical phenomenon with the action mode of the RpoS gene (RNA polymerase, sigma $S$ ), which is responsible for activating several anti-stress responses, such as osmo-protection, even if stresses are a result of different causes. The authors highlight that initially pre-stressed bacteria are more likely to survive potential following stresses. This behavior could influence the design of solar treatment systems, so as bacteria receive only the necessary dose (as defined in the previous paragraph) before they are introduced in the receiving water bodies.

Considering the applied dose, Table 2 summarizes its effects on bacterial survival as a function of the dilution rate and receiving medium. In the rows, the kinetic curves that reflect a recovery in the cultivability of bacteria are shown, in relation with dilution per medium. Literature suggests that the lack of nutrients inflicts the smallest vital changes, in short term. However, when microorganisms have to cope with a combined stress of food source deprivation and, for instance, hyperosmotic adaptation, cells' energy capacities are depleted and membrane transport is limited [57]. The experimental findings are in accordance with the literature, 
supported by the data in Table 2. It is also true that sunlight leads to restriction of cell division due to a loss of cultivability, so the initially inflicted stress leaves bacteria unable to repopulate.

Nevertheless, the loss of the ability to be cultivated, even in non-selective media, is a questionable method to judge whether cell division can take place [57], knowing that cultivability can be lost first by other alterations in cell physiology $[58,59]$. It is deducted from these experiments that samples with theoretically active and cultivable bacteria find it difficult to survive in hostile environments, such as high dilution in lake or seawater. It is concluded that cells do not lose their cultivability before 150 min of exposure in this intensity, being the highest value demonstrating repopulation of the sample. Adaptation is impossible and the energy reserves are devoted to cell integrity maintenance, as stated by Troussellier et al [57].

In accordance to temperature alterations, profound differences are also visible, but due to other causes. For instance, at low temperatures, only the untreated bacteria are able to increase in numbers, at $20^{\circ} \mathrm{C}$ the ones that received treatment from 0-90 min and in the most favorable temperature, 0 to 180 -min treated samples present growth. It has been reviewed lately, that temperature influences bacterial survival [42]. The findings in the same matrix, by the same pretreatment method and with bacteria bearing equal light-mediated injuries, support the temperature preference of bacteria. In addition, they reveal the positive effects that favorable conditions have on bacterial self-reparation capacities; when bacteria are in osmotic friendly environment, temperature can dominate survival kinetics, causing regrowth instead of plain survival and adaptation to the new conditions.

Certain behavioral patterns were correlated here, as a function of the osmotic difference and the availability of nutrients in the matrix. The order of increasing hostility against bacteria reflected in survival times, is as follows: sea water $<$ Mili-Q water $<$ lake water $<$ wastewater. Wastewater and its dilutions, demonstrate growth in all cases, while the negative osmotic influence of lake water induces prolonged survival, and less growth than wastewater. Sea water, especially in high dilution rates, is an unfriendly matrix and presents a deterministic decay regardless the pre-induced damage. The stressed microorganisms have to deal with acclimatization (initial 
shock) issues, which were visible in the kinetic curves and the initial stress. This shock can modify the adaptation capacities. Findings like these, have influenced propositions of introducing wastewater in deep outfalls into the sea with little treatment [60]. Finally, lake water and Mili-Q water as receiving media demonstrated mitigated hostile effects, when they received wastewater diluted in high rates, compared to seawater. This behavior could influence outfall designs especially in lake shores, and stricter pre-treatment rules should be applied in these cases. It is known that bacteria enter aquatic systems in dormant states [38] and are lead to non-cultivable phases. The results are in agreement with literature. However, we have shown that cultivability is not exclusively a function of dose, neither of dilution nor the medium alone. Temperature has also significant influence, because metabolic dormancy [24] can easily be disrupted and result to bacterial repopulation and prolonged survival in such waters [25].

\section{Conclusions}

Modification of the post-treatment conditions was experimentally examined within two groups, temperature and dilution rate in different mediums. When storage temperature was modified, different responses were observed by the pre-treated bacterial samples. Keeping samples in temperatures as low as $4^{\circ} \mathrm{C}$ inhibited growth, but prolonged bacterial survival. This prolongation was slightly correlated with the dose received during simulated solar treatment. Increasing temperature to $20^{\circ} \mathrm{C}$ permitted growth in untreated and lightly treated samples, i.e. $30-90$ min of solar illumination, and accelerated decay in the rest of the samples. Further increase of temperature lead to excess growth for all samples except for the heavily damaged 210 and 240 min treated ones; the observed growth was attributed to the temperature effects, which are combined with the presence of nutrients, to offer bacteria optimal growth conditions.

Dilution in different matrices induced various responses according to the osmotic conditions present at the sample. When the pre-illuminated samples were further diluted in wastewater, a 
subsequent growth was observed after an initial lag phase. The delay was a function of the dose during solar pre-treatment. The exact opposite findings of this nutrient-rich medium were found when treated water was introduced in Mili-Q water. Inducing osmotic pressure combined with starvation due to the lack of food source lead to deterministic decay of the samples. Lake water, although osmotically negative, prolonged survivals due to the existence of baroprotective salts. Finally, seawater demonstrated the most hostile behavior against bacteria, which were unable to cope with the difference in pressure while injured. The survival times were the lowest among the four matrices. Regardless the matrix, a pattern was observed, where bacteria that were treated for short time presented high resistance, when were diluted in unfriendly matrices and high growth rates, when growth was permitted.

The rate of employed dilution investigated various conditions, such as low dilution (50\%) up to high rates (1\%). Every matrix caused different bacterial response while being diluted. Wastewater dilutions accepted positively the dilution in fresh medium, providing higher proportions of food per cell; thus more comfortable conditions were obtained and in long term lead to the same bacterial numbers, regardless the dilution rate. Dilution in Lake Leman water, in low rates, provided good survival conditions, but as dilution was increased, survival was linked to the negative effect of food deprivation and the injuries from solar treatment. Although seawater is considered as a difficult environment for bacterial survival, in low dilution rates survival was prolonged, after a lag phase growth was initiated. When dilution was increased, decay was initiated for almost all samples (except $0-30$ min of treatment). In $1 \%$ dilution the osmotically-induced decay prevailed, resulting in decay curves for all samples. Control experiments in Mili-Q water verified the correlation between survival and osmotic stress, since high dilution rate accelerated bacterial decay, while low rates permitted growth after an initial shock/adaptation phase.

The observations in synthetic and real matrices at laboratory level, can enable better design of solar treatment systems, since some insight has been given on the bacterial survival in a controlled environment. This work presents some aspects of the complex addressed problem, 
as an exploration of the boundary conditions. For instance, the sequential shift between light and dark environment can inflict further bacterial inactivation in the recipients, during solar exposure, or their regrowth during the night. There are other crucial matters affecting the survival that need to be taken into account, such as predation by natural indigenous microorganisms or the diversity of light supply during temporal weather changes; these factors were not a subject at this work, but are currently underway in our laboratory. However, the simulated conditions provide a good approximation, with respect to the real application. Nevertheless, the philosophy behind the design of solar treatment methods can be implemented with such results that indicate possibilities for reduced retention times, one of the most decisive factors in these systems. Fecal contamination can be reduced and aid in more efficient downstream handling of effluents. In that way, strategies more suitable in the local context can be encouraged, such as safe discharge, controlled irrigation and use of reclaimed water.

\section{Acknowledgments}

The authors wish to thank, in order of acquisition, the Mediterranean Office for Youth Program (MOY, call 2011-2014), by means of which Stefanos Giannakis has received a PhD mobility grant (MOY grant $N^{0} 2010 / 044 / 01$ ) in the joint Environmental Engineering Doctoral Program. Special thanks to Marti Crespi and Mercè Vilaseca Vallvé from the INTEXTER for their academic support. Also, we thank the Swiss Government for the Swiss Government Excellence Scholarship, by means of which Stefanos Giannakis has received a Research Visit fellowship (No. 2012.0499).

\section{References}


[1] A. Campisano, J. Cabot Ple, D. Muschalla, M. Pleau, P.A. Vanrolleghem, Potential and limitations of modern equipment for real time control of urban wastewater systems, Urban Water Journal, 10 (2013) 300-311.

[2] I. Vera, K. Sáez, G. Vidal, Performance of 14 full-scale sewage treatment plants: Comparison between four aerobic technologies regarding effluent quality, sludge production and energy consumption, Environmental Technology, 34 (2013) 2267-2275.

[3] M.A. Belmont, E. Cantellano, S. Thompson, M. Williamson, A. Sánchez, C.D. Metcalfe, Treatment of domestic wastewater in a pilot-scale natural treatment system in central Mexico, Ecological Engineering, 23 (2004) 299-311.

[4] F.H. Papadopoulos, V.A. Tsihrintzis, Assessment of a full-scale duckweed pond system for septage treatment, Environmental Technology, 32 (2011) 795-804.

[5] L.W. Sinton, R.K. Finlay, P.A. Lynch, Sunlight inactivation of fecal bacteriophages and bacteria in sewage-polluted seawater, Applied and Environmental Microbiology, 65 (1999) 3605-3613.

[6] J.M. Dalu, J. Ndamba, Duckweed based wastewater stabilization ponds for wastewater treatment (a low cost technology for small urban areas in Zimbabwe), Physics and Chemistry of the Earth, Parts A/B/C, 28 (2003) 1147-1160.

[7] M.E. Kaseva, Performance of a sub-surface flow constructed wetland in polishing pre-treated wastewater-a tropical case study, Water research, 38 (2004) 681-687.

[8] J.M. Meichtry, M.A. Blesa, M.I. Litter, H.J. Lin, L. de la Fuente, I.K. Levy, E.A. Gautier, Lowcost $\mathrm{TiO} 2$ photocatalytic technology for water potabilization in plastic bottles for isolated regions. Photocatalyst fixation, Journal of Solar Energy Engineering, 129 (2007) 119-126.

[9] A. Acra, Z. Raffoul, Y. Karahagopian, Solar disinfection of drinking water and oral rehydration solutions: guidelines fo household application in developing countries, (1984). 
[10] M. Wegelin, S. Canonica, K. Mechsner, T. Fleischmann, F. Pesaro, A. Metzler, Solar water disinfection: scope of the process and analysis of radiation experiments, Journal of Water Supply: Research and Technology - Aqua, 43 (1994) 154-169.

[11] M. du Preez, R.M. Conroy, S. Ligondo, J. Hennessy, M. Elmore-Meegan, A. Soita, K.G. McGuigan, Randomized intervention study of solar disinfection of drinking water in the prevention of dysentery in Kenyan children aged under 5 years, Environmental science \& technology, 45 (2011) 9315-9323.

[12] K.G. McGuigan, R.M. Conroy, H.J. Mosler, M. du Preez, E. Ubomba-Jaswa, P. FernandezIbanez, Solar water disinfection (SODIS): a review from bench-top to roof-top, Journal of hazardous materials, 235-236 (2012) 29-46.

[13] K.G. McGuigan, P. Samaiyar, M. du Preez, R.M. Conroy, High compliance randomized controlled field trial of solar disinfection of drinking water and its impact on childhood diarrhea in rural Cambodia, Environmental science \& technology, 45 (2011) 7862-7867.

[14] R. Nalwanga, B. Quilty, C. Muyanja, P. Fernandez-Ibañez, K.G. McGuigan, Evaluation of solar disinfection of E. coli under Sub-Saharan field conditions using a $25 \mathrm{~L}$ borosilicate glass batch reactor fitted with a compound parabolic collector, Solar Energy, 100 (2014) 195-202.

[15] K. McGuigan, T. Joyce, R. Conroy, J. Gillespie, M. Elmore-Meegan, Solar disinfection of drinking water contained in transparent plastic bottles: characterizing the bacterial inactivation process, Journal of applied microbiology, 84 (1998) 1138-1148.

[16] A.-G. Rincón, C. Pulgarin, Fe 3+ and TiO2 solar-light-assisted inactivation of E. coli at field scale: Implications in solar disinfection at low temperature of large quantities of water, Catalysis today, $122(2007)$ 128-136.

[17] A.-G. Rincón, C. Pulgarin, Field solar E. coli inactivation in the absence and presence of TiO2: is UV solar dose an appropriate parameter for standardization of water solar disinfection?, Solar Energy, 77 (2004) 635-648. 
[18] J. Lonnen, S. Kilvington, S. Kehoe, F. Al-Touati, K. McGuigan, Solar and photocatalytic disinfection of protozoan, fungal and bacterial microbes in drinking water, Water research, 39 (2005) 877-883.

[19] M. Berney, H.U. Weilenmann, A. Simonetti, T. Egli, Efficacy of solar disinfection of Escherichia coli, Shigella flexneri, Salmonella Typhimurium and Vibrio cholerae, Journal of applied microbiology, 101 (2006) 828-836.

[20] J. Ndounla, D. Spuhler, S. Kenfack, J. Wéthé, C. Pulgarin, Inactivation by solar photoFenton in pet bottles of wild enteric bacteria of natural well water: Absence of re-growth after one week of subsequent storage, Applied Catalysis B: Environmental, 129 (2013) 309-317.

[21] F. Sciacca, J.A. Rengifo-Herrera, J. Wéthé, C. Pulgarin, Solar disinfection of wild Salmonella sp. in natural water with a 18L CPC photoreactor: Detrimental effect of non-sterile storage of treated water, Solar Energy, 85 (2011) 1399-1408.

[22] A.K. Kivaisi, The potential for constructed wetlands for wastewater treatment and reuse in developing countries: a review, Ecological Engineering, 16 (2001) 545-560.

[23] L.W. Sinton, C.H. Hall, P.A. Lynch, R.J. Davies-Colley, Sunlight Inactivation of Fecal Indicator Bacteria and Bacteriophages from Waste Stabilization Pond Effluent in Fresh and Saline Waters, Applied and Environmental Microbiology, 68 (2002) 1122-1131.

[24] L.M. Avery, A.P. Williams, K. Killham, D.L. Jones, Survival of Escherichia coli O157:H7 in waters from lakes, rivers, puddles and animal-drinking troughs, Science of the total environment, 389 (2008) 378-385.

[25] L. Haller, J. Poté, J.-L. Loizeau, W. Wildi, Distribution and survival of faecal indicator bacteria in the sediments of the Bay of Vidy, Lake Geneva, Switzerland, Ecological Indicators, 9 (2009) 540-547.

[26] A. Chandran, A.A. Mohamed Hatha, Relative survival of Escherichia coli and Salmonella typhimurium in a tropical estuary, Water research, 39 (2005) 1397-1403. 
[27] D. Kay, C.M. Stapleton, M.D. Wyer, A.T. McDonald, J. Crowther, N. Paul, K. Jones, C. Francis, J. Watkins, J. Wilkinson, N. Humphrey, B. Lin, L. Yang, R.A. Falconer, S. Gardner, Decay of intestinal enterococci concentrations in high-energy estuarine and coastal waters: towards real-time T90 values for modelling faecal indicators in recreational waters, Water research, 39 (2005) 655-667.

[28] N. Mezrioui, B. Baleux, M. Troussellier, A microcosm study of the survival of Escherichia coli and Salmonella typhimurium in brackish water, Water research, 29 (1995) 459-465.

[29] R.T. Noble, I.M. Lee, K.C. Schiff, Inactivation of indicator micro-organisms from various sources of faecal contamination in seawater and freshwater, Journal of applied microbiology, 96 (2004) 464-472.

[30] E. Darakas, T. Koumoulidou, D. Lazaridou, Fecal indicator bacteria declines via a dilution of wastewater in seawater, Desalination, 248 (2009) 1008-1015.

[31] Y. Chan, E. Killick, The effect of salinity, light and temperature in a disposal environment on the recovery of E. coli following exposure to ultraviolet radiation, Water research, 29 (1995) 1373-1377.

[32] L.W. Sinton, R.K. Finlay, P.A. Lynch, Sunlight inactivation of fecal bacteriophages and bacteria in sewage-polluted seawater, Applied and Environmental Microbiology, 65 (1999) 3605-3613.

[33] M.A. Yukselen, B. Calli, O. Gokyay, A. Saatci, Inactivation of coliform bacteria in Black Sea waters due to solar radiation, Environment International, 29 (2003) 45-50.

[34] M.B. Jenkins, D.M. Endale, D.S. Fisher, M.P. Adams, R. Lowrance, G.L. Newton, G. Vellidis, Survival dynamics of fecal bacteria in ponds in agricultural watersheds of the Piedmont and Coastal Plain of Georgia, Water research, 46 (2012) 176-186. 
[35] C. Shang, L.M. Cheung, C.-M. Ho, M. Zeng, Repression of photoreactivation and dark repair of coliform bacteria by $\mathrm{TiO} 2$-modified UV-C disinfection, Applied Catalysis B: Environmental, 89 (2009) 536-542.

[36] H.A. Munshi, N. Sasikumar, A. Jamaluddin, K. Mohammed, Evaluation of ultra-violet radiation disinfection on the bacterial growth in the SWRO pilot plant, Al-Jubail, in: Gulf Water Conference, 1999.

[37] E.A. Tassoula, Growth possibilities of E.Coli in natural waters, International Journal of Environmental Studies, 52 (1997) 67-73.

[38] D. Roszak, R. Colwell, Survival strategies of bacteria in the natural environment, Microbiological reviews, 51 (1987) 365.

[39] M. Berney, H.-U. Weilenmann, T. Egli, Adaptation to UVA radiation of E. coli growing in continuous culture, Journal of Photochemistry and Photobiology B: Biology, 86 (2007) 149-159.

[40] S. Giannakis, A.I. Merino Gamo, E. Darakas, A. Escalas-Cañellas, C. Pulgarin, Impact of different light intermittence regimes on bacteria during simulated solar treatment of secondary effluent: Implications of the inserted dark periods, Solar Energy, 98, Part C (2013) 572-581.

[41] H. Jonkers, D. Palin, P. Flink, A. Thijssen, Microbially mediated carbonation of marine alkaline minerals: Potential for concrete crack healing, (2013).

[42] R.A. Blaustein, Y. Pachepsky, R.L. Hill, D.R. Shelton, G. Whelan, Escherichia coli survival in waters: temperature dependence, Water research, 47 (2013) 569-578.

[43] J. Marugán, R. van Grieken, C. Pablos, C. Sordo, Analogies and differences between photocatalytic oxidation of chemicals and photocatalytic inactivation of microorganisms, Water research, $44(2010)$ 789-796.

[44] L. Caballero, K. Whitehead, N. Allen, J. Verran, Inactivation of Escherichia coli on immobilized $\mathrm{TiO} 2$ using fluorescent light, Journal of Photochemistry and Photobiology A: Chemistry, 202 (2009) 92-98. 
[45] C. Stephens, Senescence: even bacteria get old, Current Biology, 15 (2005) R308-R310.

[46] C. Hallmich, R. Gehr, Effect of pre-and post-UV disinfection conditions on photoreactivation of fecal coliforms in wastewater effluents, Water research, 44 (2010) 2885-2893.

[47] F. Bosshard, M. Bucheli, Y. Meur, T. Egli, The respiratory chain is the cell's Achilles' heel during UVA inactivation in Escherichia coli, Microbiology, 156 (2010) 2006-2015.

[48] B. Sat, R. Hazan, T. Fisher, H. Khaner, G. Glaser, H. Engelberg-Kulka, Programmed Cell Death in Escherichia coli: Some Antibiotics Can Trigger mazEFLethality, Journal of bacteriology, 183 (2001) 2041-2045.

[49] J. Dahlén, S. Bertilsson, C. Pettersson, Effects of UV-A irradiation on dissolved organic matter in humic surface waters, Environment International, 22 (1996) 501-506.

[50] K.G. Lindenauer, J.L. Darby, Ultraviolet disinfection of wastewater: effect of dose on subsequent photoreactivation, Water research, 28 (1994) 805-817.

[51] K. Flint, The Iong-term survival of Escherichia coli in river water, Journal of applied microbiology, 63 (1987) 261-270.

[52] E. Darakas, A simple mathematical formula describing the survival kinetics of $E$. coli in natural waters, International journal of environmental studies, 58 (2001) 365-372.

[53] L. Yang, W.-S. Chang, M.-N. Lo Huang, Natural disinfection of wastewater in marine outfall fields, Water research, 34 (2000) 743-750.

[54] E. Darakas, E. coli kinetics-effect of temperature on the maintenance and respectively the decay phase, Environmental monitoring and assessment, 78 (2002) 101-110.

[55] P.H. Quek, J. Hu, Indicators for photoreactivation and dark repair studies following ultraviolet disinfection, Journal of industrial microbiology \& biotechnology, 35 (2008) 533-541.

[56] FAO Corporate Document Repository, Site Selection for Aquaculture: Physical Features of Water, M.N. Kutty, 1987, http://www.fao.org/docrep/field/003/ac174e/AC174E00.htm\#TOC, last accessed: $27 / 10 / 2013$ 
[57] M. Troussellier, J.-L. Bonnefont, C. Courties, A. Derrien, E. Dupray, M. Gauthier, M. Gourmelon, F. Joux, P. Lebaron, Y. Martin, Responses of enteric bacteria to environmental stresses in seawater, Oceanologica Acta, 21 (1998) 965-981.

[58] W.G. Roth, M.P. Leckie, D.N. Dietzler, Restoration of colony-forming activity in osmotically stressed Escherichia coli by betaine, Applied and environmental microbiology, 54 (1988) 31423146.

[59] F.J. Genthner, J. Upadhyay, R.P. Campbell, B.R.S. Genthner, Anomalies in the enumeration of starved bacteria on culture media containing nalidic acid and tetracycline, Microbial ecology, 20 (1990) 283-288.

[60] L. Yang, W.-S. Chang, M.-N. Lo Huang, Natural disinfection of wastewater in marine outfall fields, Water research, 34 (2000) 743-750.

[61] S. Giannakis, E. Darakas, A. Escalas-Cañellas, C. Pulgarin, The antagonistic and synergistic effects of temperature during solar disinfection of synthetic secondary effluent, Journal of Photochemistry and Photobiology A: Chemistry, 280 (2014) 14-26.

[62] A.-G. Rincón, C. Pulgarin, Bactericidal action of illuminated TiO2 on pure Escherichia coli and natural bacterial consortia: post-irradiation events in the dark and assessment of the effective disinfection time, Applied Catalysis B: Environmental, 49 (2004) 99-112. 


\section{List of Tables}

Table 1: Physicochemical characteristics of Lake Leman water (yearly average), synthetic wastewater and

\begin{tabular}{llllll}
\hline Parameter & Unit & Average & Parameter & Unit & Average \\
\hline Turbidity & NTU & 0.64 & Nitrates & $\mathrm{mg} / \mathrm{L}$ & 2.1 \\
Temperature & ${ }^{\circ} \mathrm{C}$ & 6.3 & Fluorides & $\mathrm{mg} / \mathrm{L}$ & 0 \\
$\mathrm{pH}$ & & 7.94 & Nitrites & $\mathrm{mg} / \mathrm{L}$ & 0.005 \\
Conductivity & $\mu \mathrm{S} / \mathrm{cm}$ & 274 & Ammonium & $\mathrm{mg} / \mathrm{L}$ & 0.033 \\
\hline
\end{tabular}

sea water

composition 


\begin{tabular}{|c|c|c|c|c|c|}
\hline Acid Consumption & $\mathrm{mmol} / \mathrm{L}$ & 1.87 & Aluminum & $m g / L$ & 0.021 \\
\hline $\begin{array}{l}\text { Hydrogen } \\
\text { Carbonates }\end{array}$ & $m g / L$ & 110.9 & Total Iron & $m g / L$ & 0.018 \\
\hline Hardness & 9 & 9.3 & $\begin{array}{l}\text { Total } \\
\text { Manganese }\end{array}$ & $m g / L$ & 0.001 \\
\hline Total Hardness & 9 & 13.7 & Phosphor direct & $m g p / L$ & 0.018 \\
\hline Active $\mathrm{CO}_{2}$ & $m g / L$ & 0.4 & Silica & $m g / L$ & 0.8 \\
\hline Saturation Index & & -0.06 & Cuprum & $\mu g / L$ & 1.3 \\
\hline Dissolved Oxygen & $m g / L$ & 9.5 & Zinc & $\mu g / L$ & 3.9 \\
\hline$\%$ saturation & $\%$ & 83.4 & Cadmium & $\mu g / L$ & 0 \\
\hline Oxidization $\mathrm{KMnO}_{4}$ & $m g / L$ & 2.5 & Lead & $\mu g / L$ & 0.2 \\
\hline Absorbance $254 \mathrm{~nm}$ & $/ m$ & 1.557 & Chromium & $\mu g / L$ & 0.8 \\
\hline $\begin{array}{ll}\text { Total } & \text { Organic } \\
\text { Carbon } & \end{array}$ & $m g C / L$ & 0.72 & Cobalt & $\mu g / L$ & 0 \\
\hline Calcium & $m g / L$ & 44.8 & Nickel & $\mu g / L$ & 0.4 \\
\hline Magnesium & $m g / L$ & 5.9 & $\mathrm{CHCl}_{3}$ & $\mu g / L$ & 0 \\
\hline Sodium & $m g / L$ & 6.7 & $\mathrm{CHCl}_{2} \mathrm{Br}$ & $\mu g / L$ & 0 \\
\hline Potassium & $m g / L$ & 1.6 & $\mathrm{CHClBr}_{2}$ & $\mu g / L$ & 0 \\
\hline Chlorides & $m g / L$ & 9.4 & $\mathrm{CHBr}_{3}$ & $\mu g / L$ & 0 \\
\hline Sulfates & $m g / L$ & 48.8 & Trihalomethanes & $\mu g / L$ & 0 \\
\hline $\begin{array}{l}\text { Wastewater } \\
\text { Composition }\end{array}$ & $\begin{array}{l}\text { (Giannakis } \\
\text { et al., } \\
\text { 2013) }\end{array}$ & & $\begin{array}{l}\text { Seawater } \\
\text { Composition }\end{array}$ & $\begin{array}{l}\text { (Jonkers } \\
\text { et al., } \\
\text { 2013) }\end{array}$ & \\
\hline Peptone & $160 \mathrm{mg} / \mathrm{L}$ & & $\mathrm{NaCl}$ & $27.35 \mathrm{~g} / \mathrm{L}$ & \\
\hline Meat Extract & $110 \mathrm{mg} / \mathrm{L}$ & & $\mathrm{KCl}$ & $0.8 \mathrm{~g} / \mathrm{L}$ & \\
\hline Urea & $30 \mathrm{mg} / \mathrm{L}$ & & $\mathrm{CaCl} 2 \cdot 2 \mathrm{H}_{2} \mathrm{O}$ & $1.5 \mathrm{~g} / \mathrm{L}$ & \\
\hline $\mathrm{K}_{2} \mathrm{HPO}_{4}$ & $28 \mathrm{mg} / \mathrm{L}$ & & $\mathrm{MgSO}_{4} \cdot 7 \mathrm{H}_{2} \mathrm{O}$ & $6.9 \mathrm{~g} / \mathrm{L}$ & \\
\hline $\mathrm{NaCl}$ & $7 \mathrm{mg} / \mathrm{L}$ & & $\mathrm{MgCl}_{2} \cdot 6 \mathrm{H}_{2} \mathrm{O}$ & $5.1 \mathrm{~g} / \mathrm{L}$ & \\
\hline $\mathrm{CaCl}_{2} \cdot 2 \mathrm{H}_{2} \mathrm{O}$ & $4 \mathrm{mg} / \mathrm{L}$ & & Salinity & $3.5 \%$ & \\
\hline $\mathrm{MgSO}_{4} \cdot 7 \mathrm{H}_{2} \mathrm{O}$ & $2 \mathrm{mg} / \mathrm{L}$ & & & & \\
\hline
\end{tabular}


Table 2: Summary of kinetic curves presenting post-irradiation growth

\begin{tabular}{llll}
\hline & $\mathbf{5 0 \%}$ & $\mathbf{1 0 \%}$ & $\mathbf{1 \%}$ \\
\hline Wastewater & $0-150 \mathrm{~min}$ & $0-150 \mathrm{~min}$ & $0-120 \mathrm{~min}$ \\
Lake Water & $0-120 \mathrm{~min}$ & $0-90 \mathrm{~min}$ & $0-30 \mathrm{~min}$ \\
Seawater & $0-120 \mathrm{~min}$ & $0-30 \mathrm{~min}$ & - \\
Mili-Q Water & $0-120 \mathrm{~min}$ & $0-60 \mathrm{~min}$ & - \\
& $\mathbf{4}^{\circ} \mathrm{C}$ & $\mathbf{2 0} \mathrm{C}$ & $\mathbf{3 7} \mathbf{0}^{\circ} \mathrm{C}$ \\
Undiluted Wastewater & $0 \mathrm{~min}$ & $0-90 \mathrm{~min}$ & $0-180 \mathrm{~min}$ \\
\hline
\end{tabular}




\section{List of Figures}

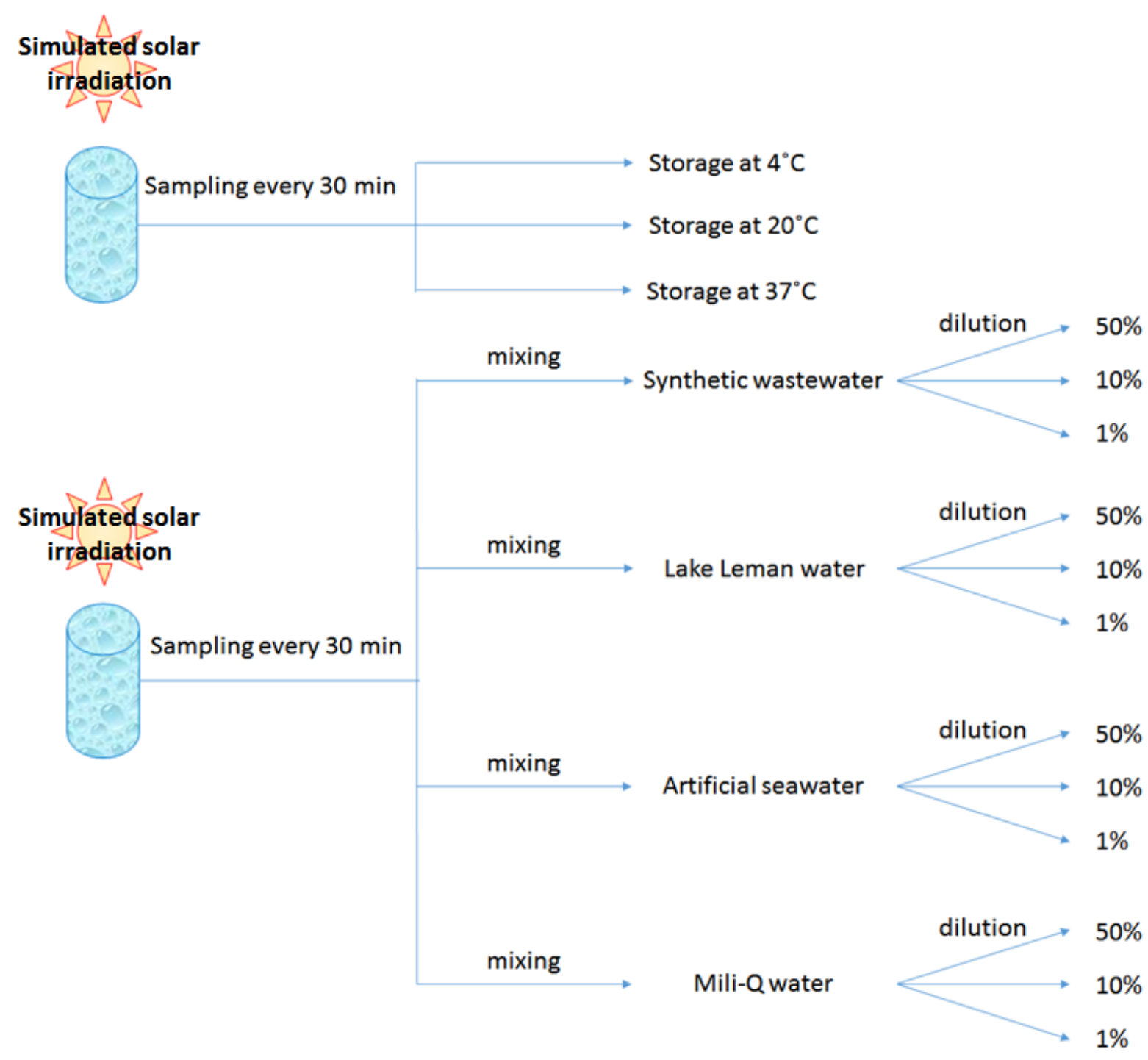

Figure 1: Schematic representation of the experimental strategies. An irradiated batch was split to three samples for temperature control, and another batch was divided into the four matrices and the subsequent dilutions. 

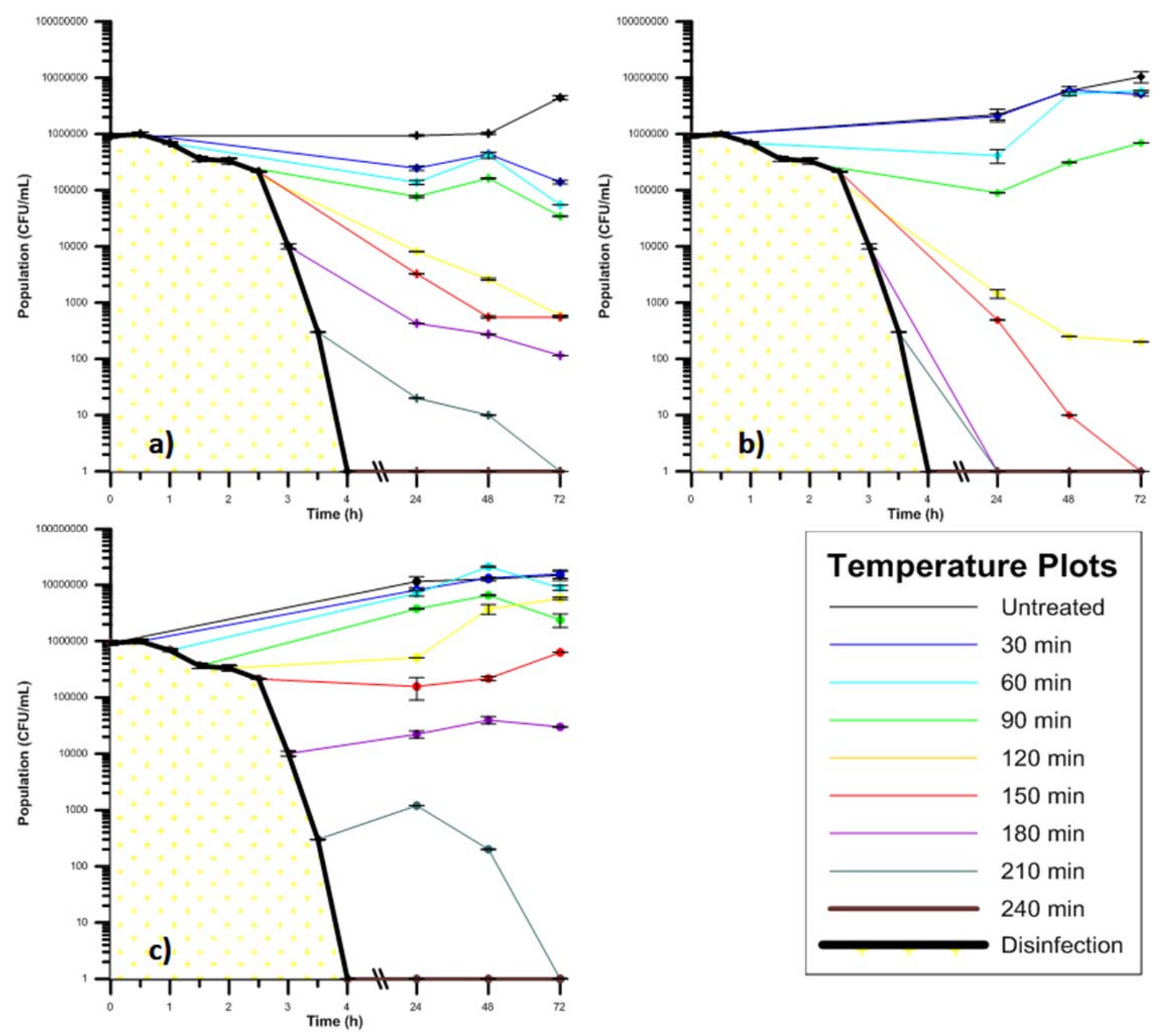

\section{Temperature Plots}

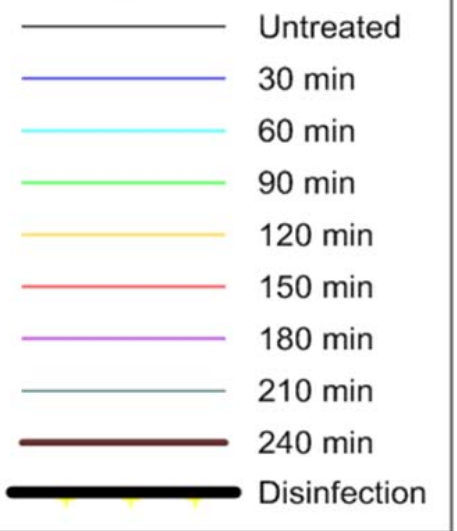

Figure 2: Post-irradiation monitoring at different temperature levels. Samples were kept for three days at: (a) $4^{\circ} \mathrm{C}$. (b) $20^{\circ} \mathrm{C}$. (c) $37^{\circ} \mathrm{C}$. 

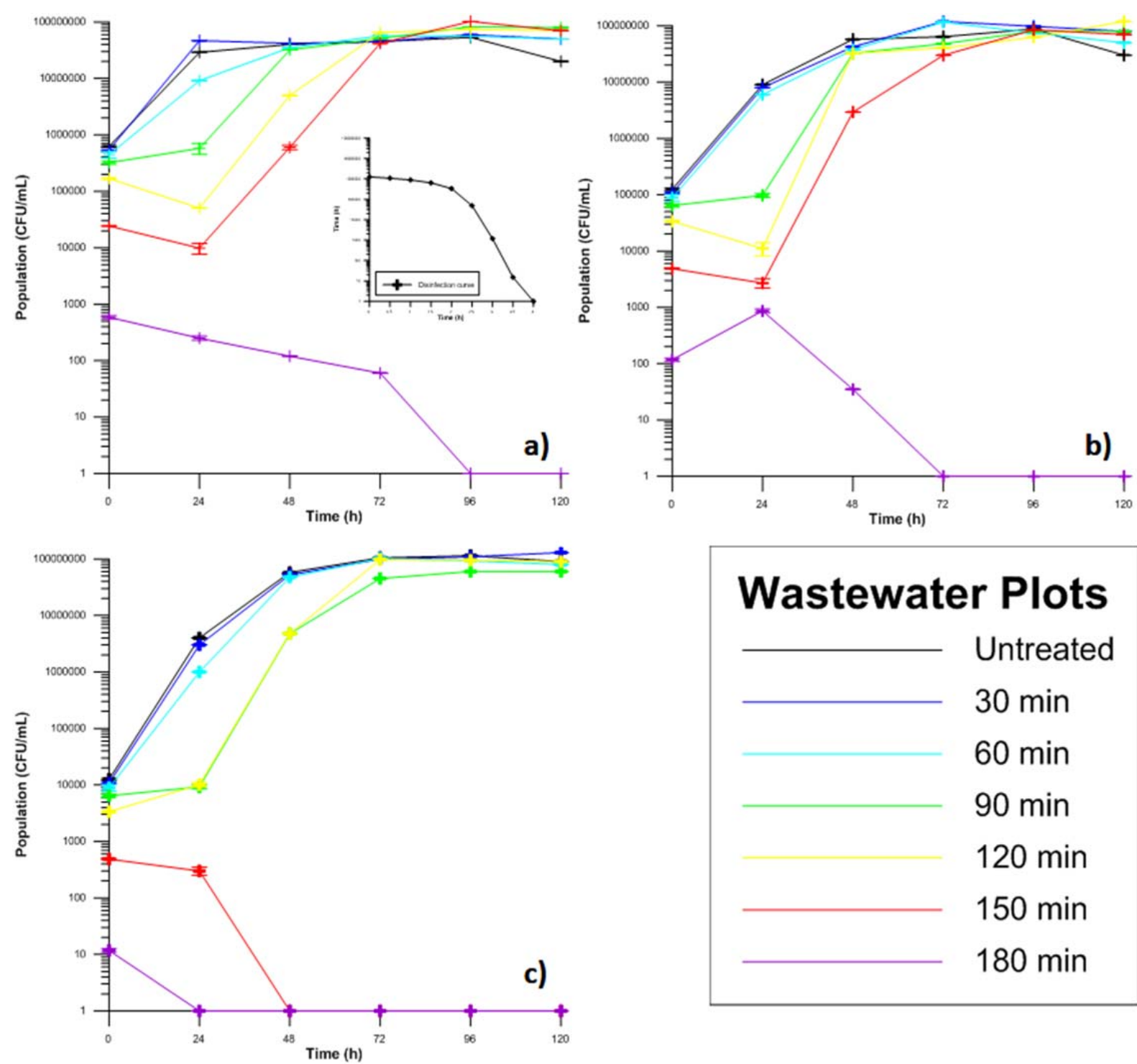

\section{Wastewater Plots}

Untreated

$30 \mathrm{~min}$

$60 \mathrm{~min}$

$90 \min$

$120 \mathrm{~min}$

$150 \mathrm{~min}$

$180 \mathrm{~min}$

Figure 3: Overview of the 5-day monitoring period of the irradiated sample diluted in wastewater. (a) $50 \%$ dilution. (b) $10 \%$ dilution. (c) $1 \%$ dilution. 

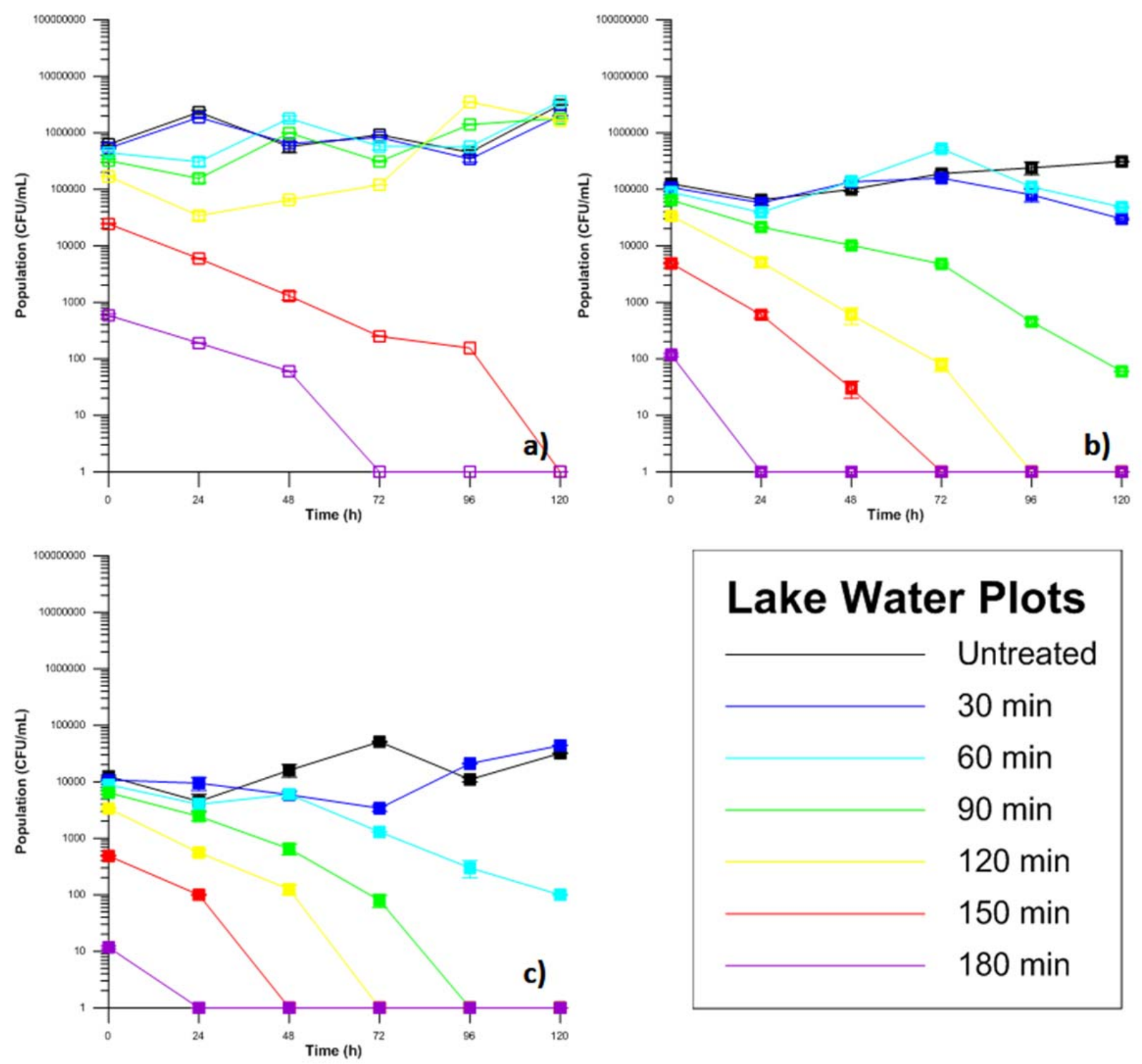

Lake Water Plots

Untreated

$30 \mathrm{~min}$

$60 \mathrm{~min}$

$90 \mathrm{~min}$

$120 \mathrm{~min}$

$150 \mathrm{~min}$

$180 \mathrm{~min}$

Figure 4: Overview of the 5-day monitoring period of the irradiated sample diluted in Lake Leman water.

(a) $50 \%$ dilution. (b) $10 \%$ dilution. (c) $1 \%$ dilution. 

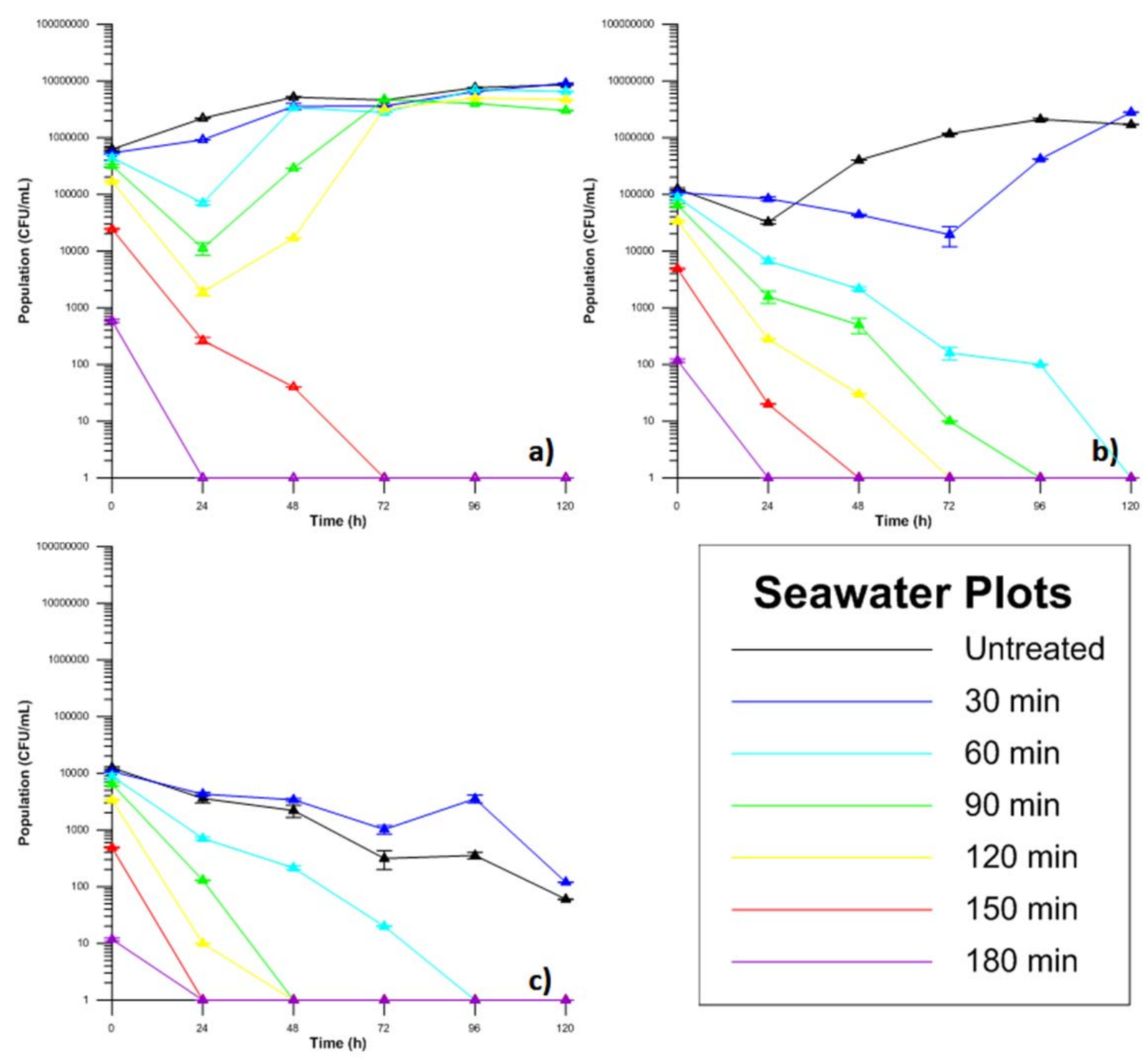

\section{Seawater Plots}

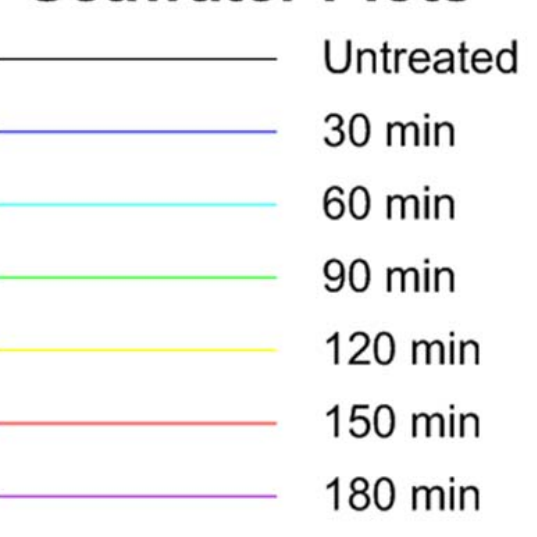

Figure 5: Overview of the 5-day monitoring period of the irradiated sample diluted in synthetic seawater. (a) $50 \%$ dilution. (b) $10 \%$ dilution. (c) $1 \%$ dilution. 

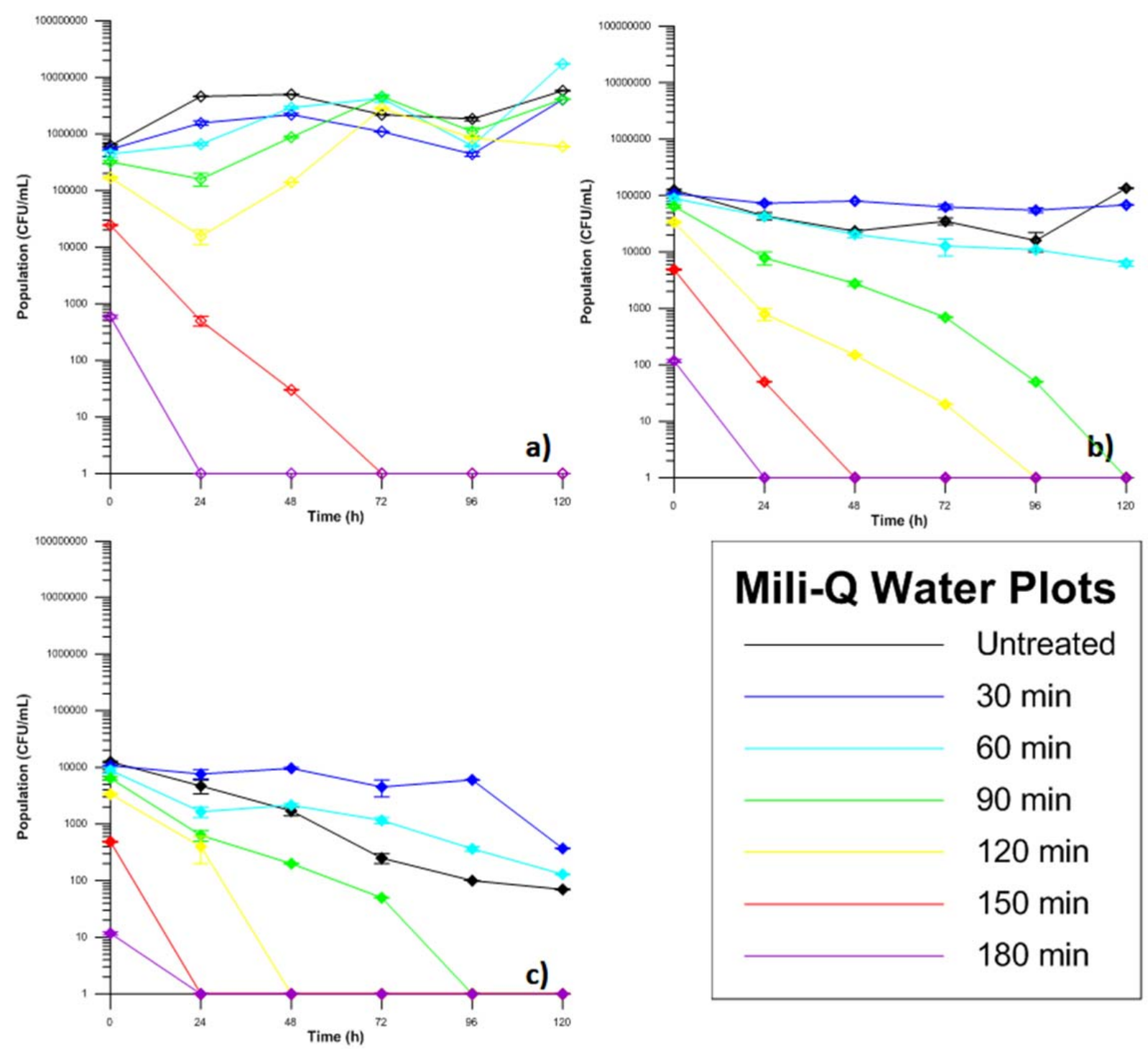

\section{Mili-Q Water Plots}

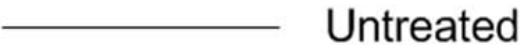

$30 \mathrm{~min}$

$60 \mathrm{~min}$

$90 \min$

$120 \mathrm{~min}$

$150 \mathrm{~min}$

$180 \mathrm{~min}$

Figure 6: Overview of the 5-day monitoring period of the irradiated sample diluted in Mili-Q water. (a) $50 \%$ dilution. (b) $10 \%$ dilution. (c) $1 \%$ dilution. 